\title{
TRANSESTERIFIKASI MINYAK BIJI KARET (Hevea brasiliensis) MENGGUNAKAN KATALIS HETEROGEN CANGKANG KEPITING LIMBAH SEAFOOD TERMODIFIKASI $\mathrm{K}_{2} \mathrm{O}$
}

\author{
N K. D. Astuti*, I N. Simpen dan I W. Suarsa \\ Program Studi Kimia FMIPA Universitas Udayana, Bukit Jimbaran, Bali \\ *Email :dididian21@gmail.com
}

\begin{abstract}
ABSTRAK
Katalis heterogen $\mathrm{CaO}$ dibuat melalui kalsinasi $\mathrm{CaCO}_{3}$ dari salah satu sumber $\mathrm{CaCO}_{3}$ yaitu cangkang kepiting limbah seafood. Pembuatan katalis heterogen tersebut telah berhasil dilakukan selanjutnya dimodifikasi dengan $\mathrm{KOH}$, secara metode impregnasi basah dan kalsinasi pada $800^{\circ} \mathrm{C}$ selama 5 jam. Tujuan dari penelitian ini adalah mengetahui karakteristik fisik dan kimia katalis heterogen dari cangkang kepiting dan termodifikasi $\mathrm{K}_{2} \mathrm{O}$ serta mengetahui kinerja katalis heterogen cangkang termodifikasi tersebut dalam mengkonversi minyak biji karet menjadi biodiesel. Hasil penelitian menunjukkan bahwa kebasaan permukaan terendah dimiliki katalis tanpa modifikasi $\left(1,0428 \mathrm{mmol} \mathrm{g}^{-1}\right)$ dan kebasaan tertinggi dimiliki katalis termodifikasi $\mathrm{K}_{2} \mathrm{O}\left(1,8314 \mathrm{mmol} \mathrm{g}^{-}\right.$ $\left.{ }^{1}\right)$. Karakterisasi luas permukaan spesifik cangkang kepiting tanpa modifikasi dan termodifikasi $\mathrm{K}_{2} \mathrm{O}$ relatif sama. Morfologi permukaan katalis tanpa dan termodifikasi $\mathrm{K}_{2} \mathrm{O}$ yang terbentuk tidak uniform. Hasil pemanfaatan katalis untuk transesterifikasi minyak biji karet (Hevea brasiliensis) menjadi biodiesel, diperoleh konsentrasi katalis optimum adalah 3\% dan perbandingan rasio molar minyak::metanol optimum 1:9 dengan kemampuan konversi menjadi biodiesel yield $91,05 \%$. Kandungan metil ester pada biodiesel yang dihasilkan, yaitu metil stearat, metil linoleat, metil linolenat, dan metil palmiat.
\end{abstract}

Kata kunci: katalis heterogen, cangkang kepiting termodifikasi kalium, minyak biji karet, biodiesel

\begin{abstract}
The $\mathrm{CaO}$ heterogeneous catalysts can be prepared by $\mathrm{CaCO}_{3}$ calcination process, with one source of $\mathrm{CaCO}_{3}$ being a crab shell from seafood waste. The preparation of the heterogeneous catalyst was successfully carried out by modification with $\mathrm{KOH}$ using a wet impregnation method at $800^{\circ} \mathrm{C}$ for 5 hours. The purpose of this research is to determine the physical and chemical characteristics of heterogeneous catalyst of $\mathrm{K}_{2} \mathrm{O}$ modified crab shell and to examine the heterogeneous catalyst of $\mathrm{K}_{2} \mathrm{O}$-modified shells in converting rubber seed oil into biodiesel. The results showed that the lowest basic alkalinity possessed without modified catalyst $\left(1.0428 \mathrm{mmol} \mathrm{g}^{-1}\right)$ and the highest alkali possessed potassium-modified catalyst $\left(1.8314 \mathrm{mmol}^{-1}\right)$. Characterization of specific surface area of crab shells without and with modified $\mathrm{K}_{2} \mathrm{O}$ were relatively the same. The surface morphology of the catalyst without and $\mathrm{K}_{2} \mathrm{O}$ modified was uniform. The catalyst examination results for conversion of rubber seed oil (Hevea brasiliensis) to biodiesel, the optimum catalyst concentration of $3 \%$ and the molar ratio of oil:methanol of 1:9 capable converting to biodiesel with the yield of $91.05 \%$. The content of biodiesel were stearic methyl ester, linoleic methyl ester, linolenic methyl ester, and palmitic methyl ester.
\end{abstract}

Keywords: heterogeneous catalyst, $\mathrm{K}_{2} \mathrm{O}$-modified crab shell, rubber seed oil, biodiesel

\section{PENDAHULUAN}

Biodiesel secara umum didefinisikan sebagai ester monoalil dari minyak nabati dan lemak hewani (Srivastava et al., 2000). Biodiesel dapat diproduksi melalui proses transesterifikasi menggunakan minyak nabati atau lemak hewani dengan alkohol rantai pendek menggunakan katalis homogen berupa basa kuat, seperti $\mathrm{KOH}$ atau $\mathrm{NaOH}$ (Knothe et al., 2005). Biodiesel adalah salah satu energi alternatif yang dapat diperbaharui, rendah emisi, dan biodegradable. Pada penelitian ini biodiesel dibuat menggunakan minyak biji karet (Hevea brasiliensis) yang merupakan minyak nonpangan dan memiliki kandungan minyak relativ tinggi (40-50\% berat), dimana sangat potensial sebagai bahan baku biodiesel (Bobade et al., 2012). Pemilihan tanaman karet sebagai bahan baku biodiesel juga oleh karena ketersediaan bahan bakunya yang melimpah di Indonesia. Indonesia merupakan salah satu negara yang 
mempunyai areal perkebunan karet yang luas, dimana dari perkebunan karet inilah selain menghasilkan getah karet, juga menghasilkan biji keret yang merupakan hasil samping yang belum dimanfaatkan secara optimal.

Penggunaan katalis homogen dalam produksi biodiesel memiliki keuntungan, diantaranya dapat meningkatkan laju reaksi dan konversi menjadi biodiesel relatif lebih banyak, akan tetapi penggunaan katalis homogen berdampak pada proses pemurnian dan pencucian produk akhir yang kurang ramah lingkungan. Disamping itu, pemisahannya juga relativ lebih rumit karena produk akhir bercampur dengan katalis, mengingat keduanya memiliki fase yang sama (Sharma et al., 2011). Katalis homogen juga memiliki kecenderungan meningkatkan korosivitas biodiesel bila digunakan pada mesin (Lee et al., 2014). Sedangkan katalis heterogen, memiliki banyak keunggulan dibandingkan katalis homogen, diantaranya produksi biodiesel hanya menggunakan sedikit unit opreasi dengan kemudihan pemisahan dan pemurnian produk. Katalis basa heterogen memilki keunggulan lebih mudah dipisahkan dari produk dan dapat digunakan untuk proses berkelanjutan (Sivasami et al., 2009). Katalis heterogen juga bersifat nonkorosif, non-toksik dan dapat diregenerasi setelah digunakan (Guo et al., 2011).

Kalsium oksida $(\mathrm{CaO})$ merupakan oksida logam alkali tanah yang memiliki sifat basa yang tinggi. Kebasaan $\mathrm{CaO}$ yang tinggi menyebabkan oksida ini banyak digunakan sebagai katalis pada proses transesterifikasi minyak menjadi biodiesel. Salah satu keunggulan dari $\mathrm{CaO}$ adalah berbentuk padat sehingga mudah dipisahkan pada akhir reaksi dalam proses pembuatan biodiesel. $\mathrm{CaO}$ dapat diperoleh secara komersial di pasaran, namun $\mathrm{CaO}$ komersial sulit didapat dalam keadaan murni dan harganya relatif mahal. Oleh karena itu, untuk mengatasi persoalan tersebut $\mathrm{CaO}$ dari sumber alami merupakan upaya dalam mendayagunakan limbah. Sumber-sumber alami seperti batu kapur, tulang hewan, dan cangkang banyak mengandung $\mathrm{CaCO}_{3}$ dan selanjutnya dapat didekomposisi menjadi $\mathrm{CaO}$ pada suhu tertentu. Berbagai penelitian telah dilakukan untuk memperoleh $\mathrm{CaO}$ dari sumber alami tersebut. Setiowati (2014) melaporkan bahwa dengan kalsinasi cangkang kepiting pada suhu $800^{\circ} \mathrm{C}$ selama 5 jam diperoleh persentase $\mathrm{CaO}$ sebesar $70,20 \%$. Oleh karena itu, $\mathrm{CaCO}_{3}$ pada cangkang kepiting dapat digunakan sebagai bahan baku potensial menjadi $\mathrm{CaO}$. Disisi lain, produksi biodiesel ini dinilai belum optimal karena konversi trigliserida menjadi biodiesel masih relatif rendah. Salah satu penyebab rendahnya produksi biodiesel adalah kinerja katalis yang belum optimal. Menurut Istadi (2013), upaya yang dilakukan untuk meningkatkan kinerja katalis adalah dengan penambahan situs aktif (promotor) berupa basa pada katalis $\mathrm{CaO}$ dengan metode impregnasi. Hal ini bertujuan untuk meningkatkan kebasaan dan memperluas permukaan dari katalis, sehingga dapat meningkatkan perolehan biodiesel.

Aktivitas katalitik dari katalis $\mathrm{CaO}$ dapat ditentukan dari kebasaan permukaan dan luas permukaan katalis. Berdasarkan penelitian Meher dkk. (2006) serta Kumar dan Ali (2012), penyisipan logam $\mathrm{Li}$ pada katalis $\mathrm{CaO}$ dapat meningkatkan kebasaan dan memperluas permukaan katalis. Menurut Kumar dan Ali (2012), impregnasi $\mathrm{KOH}$ pada katalis $\mathrm{CaO}$ untuk transesterifikasi produksi biodiesel menghasilkan biodiesel sebesar 96-99\% (tergantung pada bahan baku minyak nabati). Berdasarkan uraian di atas, pada penelitian ini dilakukan modifikasi katalis cangkang kepiting limbah seafood dengan impregnasi $\mathrm{KOH}$ yang dikalsinasi pada suhu $800^{\circ} \mathrm{C}$ untuk meningkatkan kinerja katalis. Katalis tersebut selanjutyan digunakan untuk reaksi transesterifikasi minyak biji karet menjadi biodiesel.

\section{MATERI DAN METODE}

\section{Bahan}

Bahan kimia yang digunakan adalah: $\mathrm{n}$ heksana $\left(\mathrm{C}_{6} \mathrm{H}_{14}\right)$, akuades, asam sulfat $\left(\mathrm{H}_{2} \mathrm{SO}_{4}\right)$, $\mathrm{KOH}$, biji karet, $\mathrm{NaOH}$, asam oksalat $1 \mathrm{M}, \mathrm{KI}$, $\mathrm{Na}_{2} \mathrm{~S}_{2} \mathrm{O}_{3}, \quad \mathrm{NaHCO}_{3}$, amilum $1 \%, \quad \mathrm{~K}_{2} \mathrm{Cr}_{2} \mathrm{O}_{7}$, indikator penolpthalein, $\mathrm{HCl}$, metanol, $\mathrm{KBr}$, kloroform dan pereaksi biuret.

\section{Alat \\ Peralatan yang adalah Fourier Transform Infrared (FTIR), Suface Area Analyzer (SAA), Gas Chromatography-Mass Spectrometer (GC- MS), Scanning Electron Microscope (SEM) dan Energy Disversive X-ray Spektroskopi (EDS), labu leher dua, statif dan klem, karet sumbat, pengaduk magnetik dan hotplate, water bath, furnace, termometer, neraca analitik, ayakan, buret, peralatan gelas, oven, blender, mortar, corong pisah, cawan porselen, desikator, pipet tetes, seperangkat alat sokhletasi, piknometer, viskometer, kondensor refluks.}




\section{Cara Kerja}

\section{Preparasi dan Modifikasi Cangkang Kepiting}

Cangkang kepiting yang diperoleh dari limbah rumah makan Kampoeng Kepiting dibersihkan terlebih dahulu dengan air panas untuk menghilangkan kotoran yang menempel. Kemudian cangkang kepiting dikeringkan dan ditumbuk sampai halus dengan menggunakan mortar. Untuk menghilangkan kandungan protein pada cangkang kepiting, bubuk cangkang kepiting direndam dengan larutan $\mathrm{NaOH} 1 \mathrm{M}$ selama 2 jam. Setelah direndam, bubuk cangkang kepiting dinetralisasi menggunakan aquades, serbuk cangkang dikeringkan dalam oven pada suhu $110^{\circ} \mathrm{C}$ selama 2 jam dan disimpan dalam desikator. Kalsinasi dilakukan dalam furnace pada suhu $800^{\circ} \mathrm{C}$ selama 5 jam. Kemudian untuk mendapatkan cangkang yang halus, serbuk cangkang diayak dengan ayakan 100 mesh.

Ditimbang katalis hasil kalsinasi disuspensikan ke dalam $200 \mathrm{~mL}$ akuades dan larutan $\mathrm{KOH} 25 \mathrm{~mL}$ dicampurkan ke dalam suspensi tersebut (\%kalium : 5\%). Campuran diaduk selama 3 jam dan dikeringkan di dalam oven pada suhu $120^{\circ} \mathrm{C}$ selama \pm 24 jam. Katalis yang dihasilkan dikalsinasi pada suhu $600^{\circ} \mathrm{C}$ selama 5 jam untuk mengubah bentuk hidroksida menjadi bentuk oksida (Niju et al., 2014). Katalis hasil impregnasi yang dihasilkan diberi kode CK-5\%. Selanjutnya, katalis dikarakterisasi sifat kebasaan permukaannya dengan titrasi asam basa, karakterisasi luas permukaan spesifik dengan BET, identifikasi gugus-gugus fungsi dengan FTIR dan karkterisasi morfologi dan kelimpahan unsur dengan SEM-EDS

\section{Penentuan kadar FFA}

Sebelum dipakai sebagai bahan baku pembuatan biodiesel, minyak biji karet yang dihasilkan dari hasil ekstraksi dari biji karet, dianalisis untuk mengetahui kandungan asam lemak bebas yang ada di dalamnya. Sampel minyak biji karet ditambah 2,5 gram dengan etanol $96 \%$ dan indikator fenolftalein, dititrasi dengan larutan $\mathrm{KOH}$ hingga berubah warna menjadi merah jambu. Volume $\mathrm{KOH}$ yang dibutuhkan dicatat untuk kemudian dipakai dalam menentukan kandungan asam lemak bebas pada sampel minyak biji karet.

\section{Uji aktivitas katalis \\ Reaksi Esterifikasi}

Proses esterifikasi dilakukan dengan metode refluks menggunakan katalis $\mathrm{H}_{2} \mathrm{SO}_{4}$. Katalis $\mathrm{H}_{2} \mathrm{SO}_{4}$ dengan persen berat katalis terhadap minyak yaltu $1 \%$ terhadap berat minyak dicampurkan ke dalam metanol dengan rasio molar minyak:metanol 1:6 sambil diaduk selama 2 jam. Reaksi dilakukan pada rentang suhu 40$60^{\circ} \mathrm{C}$. Setelah reaksi selesai, pemanasan dihentikan dan hasil reaksi dibiarkan mendingin, kemudian ditimbang beratnya sebelum dipindahkan ke dalam corong pisah. Produk yang dihasilkan, dibiarkan dalam corong pisah sampai terbentuk 2 lapisan. Lapisan bagian atas adalah produk hasil esterifikasi dan lapisan bawah adalah gliserol dan katalis. Lapisan atas dipisahkan dari lapisan gliserol dan katalis untuk selanjutnya dilakukan reaksi transesterifikasi.

\section{Reaksi Transesterifikasi}

Hasil terbaik dari reaksi esterifikasi, kemudian dilanjutkan pada proses transesterifikasi, digunakan katalis basa heterogen $\mathrm{CaO}$ termodifikasi $\mathrm{K}_{2} \mathrm{O}$. Proses transesterifikasi dilakukan dengan mencampurkan katalis dengan variasi persen berat katalis $(1,3$, dan 5\% terhadap berat minyak) ke dalam metanol dengan rasio molar minyak:metanol 1:6, 1:9, dan 1:12. Reaksi dilakukan pada suhu $60^{\circ} \mathrm{C}$ selama 60 menit dengan pengadukan konstan. Setelah reaksi selesai, pemanasan dihentikan dan hasil reaksi dibiarkan mendingin untuk kemudian ditimbang beratnya sebelum dipindahkan ke dalam corong pisah.

Produk yang dihasilkan dibiarkan dalam corong pisah selama 12 jam sampai terbentuk 2 lapisan. Lapisan bagian atas merupakan produk (biodiesel) dan lapisan bawah merupakan lapisan gliserol dan katalis. Lapisan atas dipisahkan dari lapisan bawah kemudian disaring hingga diperoleh hasil yang jernih. Selanjutnya didestilasi pada temperatur $65^{\circ} \mathrm{C}$ untuk menghilangkan sisa metanol. Biodiesel yang dihasilkan kemudian ditimbang dan dihitung yield-nya dengan rumus:

Yield biodiesel $=\frac{\text { massa biodiesel }}{\text { massa hasil transesterifikasi }} \times 100 \%$ 


\section{Analisis metil ester dengan GC-MS}

Biodiesel yang dihasilkan pada kondisi optimum diidentifikasi dengan menggunakan kromatgrafi gas-spektrometri massa (GC-MS).

\section{HASIL DAN PEMBAHASAN}

\section{Kebasaan Permukaan Katalis}

Penentuan kebasaan katalis ditentukan dengan cara titrasi asam-basa. Hasil penentuan kebasaan permukaan dan jumlah situs aktifnya ditunjukan pada Tabel 1

Tabel 1. Nilai kebasaan permukaan dan jumlah situs aktif katalis

\begin{tabular}{ccc}
\hline Jenis Katalis & $\begin{array}{c}\text { Kebasaan } \\
\text { Permukaan } \\
\left(\mathrm{mmol} \mathrm{g}^{-1}\right)\end{array}$ & $\begin{array}{c}\text { Jumlah Situs } \\
\text { Aktif Basa } \\
\left(\text { atom g }^{-1}\right)\end{array}$ \\
\hline $\mathrm{CK}_{0}$ & $1,0428 \pm 0$ & $6,2797 \times 10^{20}$ \\
$\mathrm{CK}_{5}$ & $18,8314 \pm 0$ & $1,1340 \times 10^{20}$ \\
\hline
\end{tabular}

Modifikasi cangkang kepiting dengan $\mathrm{KOH}$ mampu meningkatkan nilai kebasaan permukaan dari cangkang kepiting (Tabel 1). Kenaikan nilai kebasaan permukaan berpengaruh terhadap nilai situs aktif basa. Cangkang kepiting sebelum modifikasi memiliki kebasaan permukaan dan situs aktif basa sebesar 1,0428 \pm 0 mmol $\mathrm{g}^{-1}$ dan $6,2797 \times 10^{20}$ atom $\mathrm{g}^{-1}$. Sedangkang setelah mengalami modifikasi $\mathrm{KOH}$ dengan persentase $\mathrm{K} 5 \%$ mengalami peningkatan menjadi 18,8314 $\mathrm{mmol} \mathrm{g}^{-1}$ dan jumlah situs aktif sebesar $1,1340 \times 10^{20}$ atom g ${ }^{-1}$. Peningkatan situs basa ini didukung oleh Mulyani (2013) yang meneliti bahwa pengembanan $\mathrm{KOH}$ ke dalam

\section{Karakterisasi Gugus-gugus Fungsi Katalis dengan FTIR}

Analisis FTIR dilakukan pada bilangan gelombang 4000-500 $\mathrm{cm}^{-1}$. Gambar 1. (a) dan (b). Pada kedua sampel yang dianalisis menunjukkan adanya pita $\mathrm{OH}$ di daerah sekitar $3600 \mathrm{~cm}^{-1}$, pita $\mathrm{CH}$ di $2300-2900 \mathrm{~cm}^{-1}$, pita OC-O stretching dari karbonat muncul pada kedua sampel di bilangan gelombang $1543,05 \mathrm{~cm}^{-1}$ dan diperkuat oleh hadirnya puncak pada $1051,2 \mathrm{~cm}$ ${ }^{1}$, serta pita Ca-O pada daerah sekitar $400 \mathrm{~cm}^{-1}$.
$\mathrm{CaO}$ akan meningkatkan kebasaan. Sifat basa pada katalis sangat penting dalam pembuatan agar reaksi dapat berlangsung secara optimal (Knote et al., 2005).

\section{Karakterisasi Luas Permukaan}

Karakteristik luas permukaan spesifik ini penting karena aktivitas katalis sangat berkaitan dengan fenomena adsorpsi, dimana makin besar luas permukaan spesifik, maka makin banyak zat yang teradsorpsi. Karakteristik luas permukaan ditentukan dengan metode BET. Luas permukaan spesifik katalis ditampilkan pada Tabel 2.

Tabel 2. Luas permukaan spesifik katalis cangkang kepiting termodifikasi $\mathrm{KOH}$ dan kontrol

\begin{tabular}{rc}
\hline Jenis Katalis & $\begin{array}{c}\text { Luas Permukaan Spesifik } \\
\left(\mathrm{m}^{2} \mathrm{~g}^{-1}\right)\end{array}$ \\
\hline $\mathrm{CK}_{0}$ & 25,594 \\
$\mathrm{CK}_{5}$ & 25,877 \\
\hline
\end{tabular}

Hasil karakterisasi luas permukaan spesifik pada Tabel 2 menunjukkan bahwa luas permukaan spesifik cangkang kepiting tanpa modifikasi $\left(\mathrm{CK}_{0}\right)$ sebesar $25,594 \mathrm{~m}^{2} \mathrm{~g}^{1}$. Setelah modifikasi dengan kalium luas permukaan menjadi 25,877 $\mathrm{m}^{2} \mathrm{~g}-{ }^{1}$. Hal ini menunjukkan bahwa luas permukaan kedua sampel relatif sama. Hal ini disebabkan pendistribusian logam $\mathrm{K}$ pada permukaan katalis yang tidak merata sehingga tidak semua pori pada katalis tertutupi serta menyebabkan tidak terjadi kenaikan maupun penurunan luas permukaan spesifik pada katalis.

Serapan gugus $\mathrm{OH}$ muncul sangat tajam pada bilangan gelombang 3934,78 cm- ${ }^{1}$. Gugus $\mathrm{OH}$ dengan puncak yang tajam merupakan karakteristik dari $\mathrm{CaO}$ (Ruiz dkk., 2009). Adanya gugus $\mathrm{OH}$ dari $\mathrm{Ca}(\mathrm{OH})_{2}$ dengan karakteristik puncak yang tajam di daerah 3639,68 $\mathrm{cm}^{-1}$ dimungkinkan berasal dari molekul air yang teradsorb pada permukaan $\mathrm{CaO}$, dimana $\mathrm{CaO}$ dikenal bersifat higroskopis sehingga sangat mudah menyerap uap air dari udara (Grandos $e t$ al., 2007). 

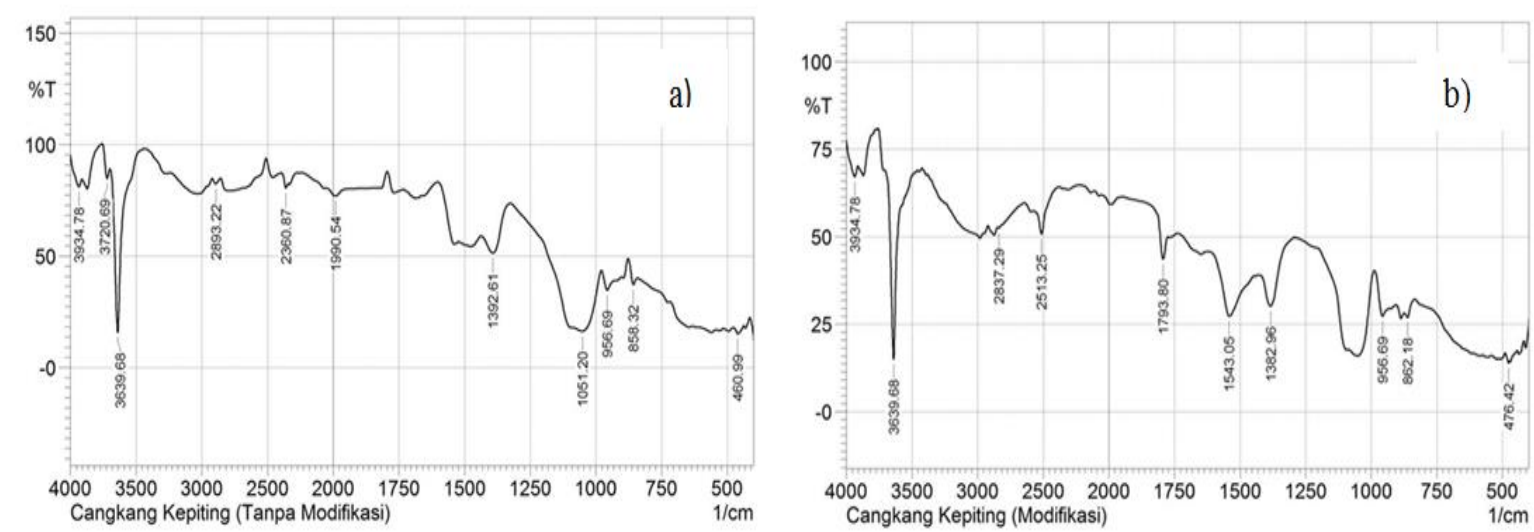

Gambar 1. (a) dan (b) Spektra FTIR sampel cangkang kepiting tanpa modifikasi dan termodifikasi

\section{Karakterisasi sifat-sifat Permukaan dengan SEM-EDS}

Analisis menggunakan SEM dilakukan untuk mengetahui morfologi permukaan dari sampel padat. SEM merupakan teknik analisis menggunakan elektron sebagai sumber pencitraan dan medan elektromagnetik sebagai lensanya. Hasil SEM dari sampel $\mathrm{CaO}$ tanpa modifikasi dan $\mathrm{CaO}$ termodifikasi $\mathrm{KOH}$ ditampilkan pada Gambar 2 (a) dan (b) dengan perbesaran 25000 kali dan EDS pada Gambar 3 (a) dan (b).

Morfologi permukaan katalis $\mathrm{CaO}$ yang dipreparasi dari cangkang kepiting limbah seafood tanpa dan dengan modifikasi $\mathrm{KOH}$ dapat dilihat bahwa katalis $\mathrm{CaO}$ yang terbentuk ukurannya mencapai skala mikrometer dan mempunyai bentuk yang tidak seragam. Oleh karena akibat kalsinasi yang dilakukan pada temperatur $800^{\circ} \mathrm{C}$ sehingga bentuk katalis menjadi tidak beraturan. Pada $\mathrm{CaO}$ termodifikasi $\mathrm{KOH}$ menunjukkan partikel yang lebih homogen dengan pori-pori tertutupi bila dibandingkan dengan $\mathrm{CaO}$ tanpa modifikasi.

Komposisi penyusun $\mathrm{CaO}$ dari cangkang kepiting tanpa modifikasi tersaji pada data EDS (Gambar 3 a), yaitu C (11,90\%), O (48,72\%), $\operatorname{Mg}(5,55 \%)$, P (1,47\%), dan Ca $(32,36 \%)$. Dari data EDS, cangkang kepiting setelah dikalsinasi mengandung $98 \%$ senyawa $\mathrm{CaO}$. Artinya proses kalsinasi telah berjalan dengan baik, yaitu membentuk $\mathrm{CaO}$ yang relatif tinggi sehingga dapat digunakan sebagai katalis untuk pembuatan biodiesel. Sementara, hasil analisis EDS $\mathrm{CaO}$ dari cangkang kepiting termodifikasi $\mathrm{KOH}$ (Gambar 3b), dengan komposisi penyusun adalah C (10,14\%), O (56,61\%), Mg (3,27\%), P (1,57\%), K (2,71\%), dan $\mathrm{Ca}(24,32 \%)$. Munculnya unsur K tersebut telah membuktikan bahwa impregnasi $\mathrm{CaO}$ dengan $\mathrm{KOH}$ telah berhasil dilakukan.

\section{Uji Kadar FFA}

Asam lemak bebas merupakan produk hidrolisis trigliserida. Reaksi ini terjadi karena hadirnya molekul air. Reaksi ini tidak terjadi secara sederhana, akan tetapi bertahap dan dapat balik (reversible). Proses hidrolisis dapat dipercepat pada suhu tinggi. Reaksi ini menghasilkan asam lemak bebas dan gliserol. Hasil penelitian menunjukkan bahwa nilai persen FFA minyak biji karet sebesar $10,43 \%$. Nilai ini lebih besar dari hasil yang diperoleh oleh Silam (1998) dan Aliem (2008), yakni masing-masing sebesar $4,91 \%$ dan $0,18 \%$. 

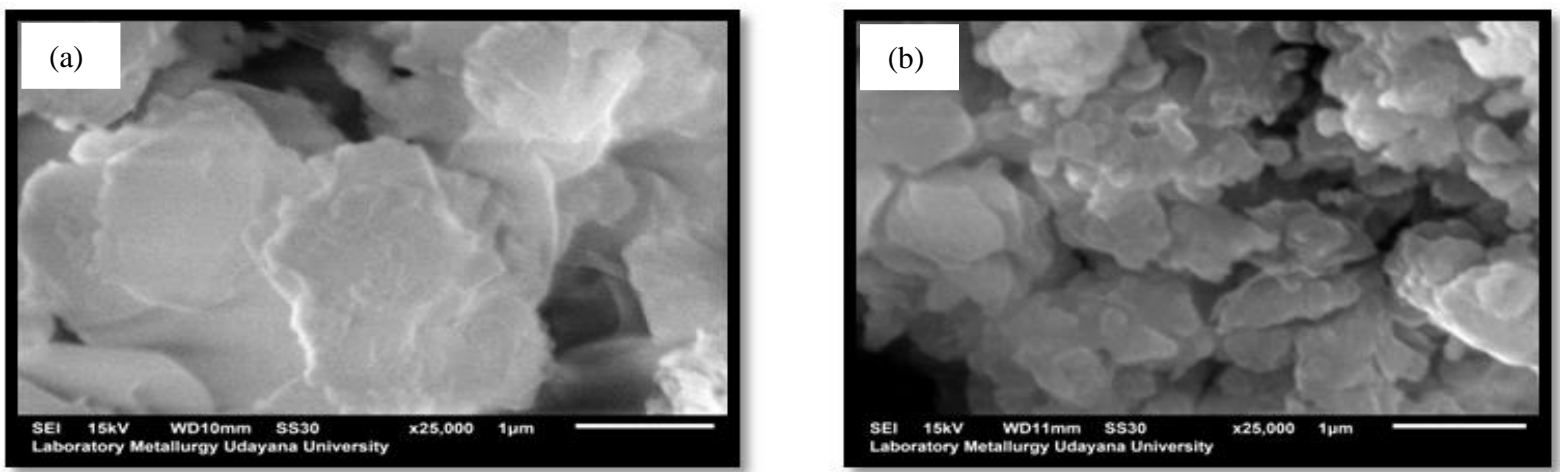

Gambar 2. Hasil SEM katalis $\mathrm{CK}_{0}$ (a) dan katalis $\mathrm{CK}_{5}$ (b)
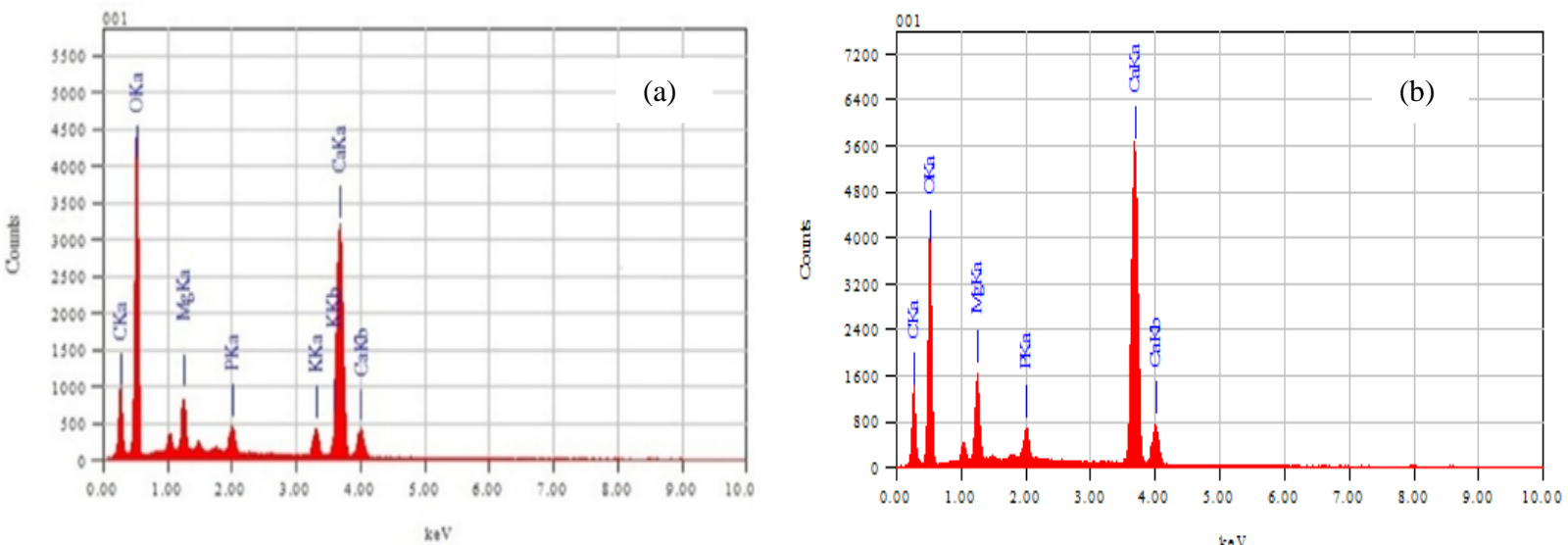

Gambar 3. Hasil EDS katalis $\mathrm{CK}_{0}$ (a) dan katalis $\mathrm{CK}_{5}$ (b)

\section{Esterifikasi}

Proses esterifikasi dilakukan untuk menurunkan kandungan asam lemak bebas minyak biji karet dengan cara mengubah asam lemak bebas menjadi alkil ester dengan mereaksikan dengan alkohol. Proses ini menggunakan katalis $\mathrm{H}_{2} \mathrm{SO}_{4} 1 \% \mathrm{~b} / \mathrm{b}$ minyak biji karet serta campuran metanol dan minyak sebesar 6:1. Pada saat proses refluks, penambahan metanol dan larutan $\mathrm{H}_{2} \mathrm{SO}_{4}$ dilakukan dalam kondisi dingin untuk menghindari terjadinya hidrolisis minyak. Reaksi yang dilakukan menggunakan perbandingan metanol 6:1 untuk menggeser kesetimbangan ke arah produk sehingga biodiesel lebih mudah didapatkan. Larutan $\mathrm{H}_{2} \mathrm{SO}_{4}$ digunakan sebagai katalis untuk mempercepat terjadinya reaksi, sedangkan metanol berfungsi untuk menyumbangkan gugus metil untuk membentuk metil ester menggantikan gugus hidrogen pada asam lemak. Dari proses ini didapatkan kadar asam lemak bebas sebesar $1,79 \%$.

Transesterifikasi dan Analisis Biodiesel

Hasil uji aktivitas katalis dalam reaksi transesterifikasi minyak biji karet menjadi biodiesel ditampilkan pada Gambar 4.

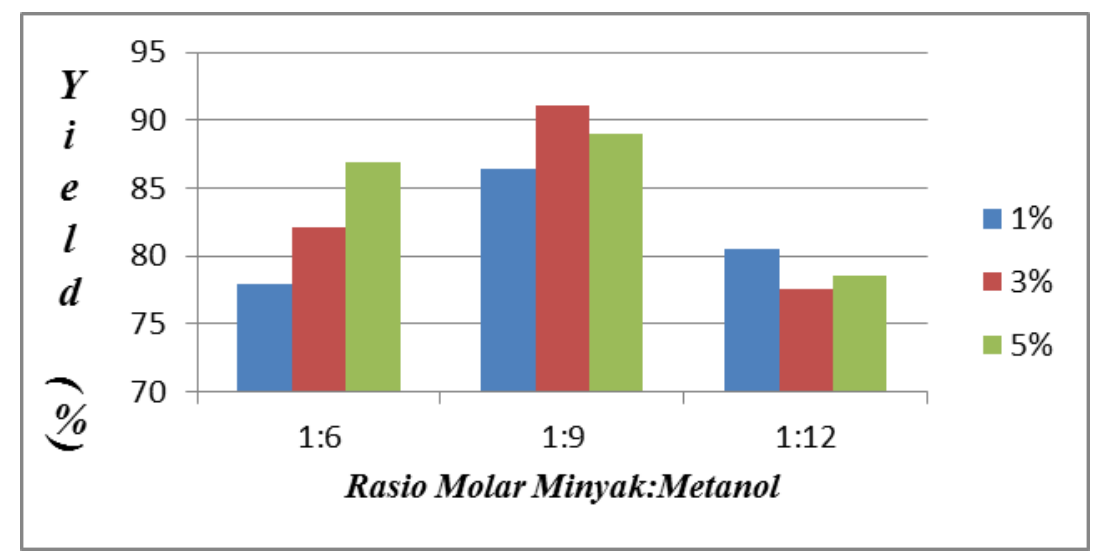

Gambar 4. Hasil uji aktivitas katalis dalam pembuatan biodiesel 
Berdasarkan Gambar 4. yield biodiesel tertinggi dihasilkan oleh katalis $\mathrm{CK}_{5}$ pada konsentrasi katalis $3 \%(\mathrm{~b} / \mathrm{b})$ dengan yield 91,05\% dengan rasio molar minyak:metanol yang optimum adalah 1:9. Abdulah et al. (2007), mengemukakan makin tinggi rasio minyak:metanol yang digunakan, maka proses pemisahan gliserol semakin sulit, karena terjadi peningkatan kelarutan gliserol di dalam metanol. Jika gliserol masih ada di dalam larutan, maka dapat menggeser kesetimbangan ke kiri, sehingga dapat menurunkan yield biodiesel. Biodiesel dengan yield tertinggi selanjutnya dianalisis kandungan metil esternya dengan GC-
MS untuk mengetahui keberhasilan reaksi pembuatan biodiesel.

Pemisahan senyawa dengan GC-MS menunjukkan 4 puncak kromatogram. Analisis dilakukan terhadap puncak-puncak dari kromatogram dengan Mass Spectrometry (MS). Hasil identifikasi puncak-puncak kromatogram berdasarkan data base pada Library ditampilkan dalam Tabel 3. Senyawa dengan puncak tertinggi yang muncul pada waktu retensi 42,758 dengan luas spektra $42,71 \%$ teridentifikasi sebagai metil linoleat, selanjutnya metil linolenat, metil sterarat dan luas spektra terendah $(7,74 \%)$ sebagai metil palmitat.

Tabel 3. Hasil identifikasi senyawa penyusun biodiesel dari minyak biji karet

\begin{tabular}{ccc}
\hline $\begin{array}{c}\text { Waktu retensi } \\
\text { (menit) }\end{array}$ & $\begin{array}{c}\text { Luas spektra } \\
(\%)\end{array}$ & Identifikasi senyawa \\
\hline 39,238 & 8,91 & Metil stearat \\
42,758 & 42,71 & Metil linoleat \\
42,903 & 40,64 & Metil linolenat \\
43,259 & 7,74 & Metil palmitat \\
\hline
\end{tabular}

\section{SIMPULAN}

Modifikasi cangkang kepiting dengan $\mathrm{KOH}$ telah mampu meningkatkan sifat kebasaan dan jumlah situs aktif, sehingga mampu mengkonversi minyak biji karet menjadi

\section{UCAPAN TERIMA KASIH}

Penulis mengucapkan terima kasih kepada ibu Emmy Sahara, ibu Ni Komang Ariati dan bapak I Wayan Suirta serta kepada semua pihak atas saran dan masukannya dalam proses penyelesaian tulisan ini.

\section{DAFTAR PUSTAKA}

Athadasi, I. M., Aroua, M. K., Azis, A. A. R, and Sulaiman, N. M. N., 2013, The Effect of Catalyst in Biodiesel Production: A Review, Journal of Industrial and Engineering Chemistry, 19(1), 14-26

Aliem, M. I., 2008, Optimasi Pengempaan Biji Karet dan Sifat Fisiko Kimia Minyak Biji Karet (Hevea brasiliensis) untuk Penyamakan Kulit, Skripsi, Departemen Hasil Hutan. Fakultas Kehutanan, Institut Pertanian Bogor biodiesel dengan yield $91,05 \%$ pada konsentrasi katalis 3\% dan rasio molar minyak:metanol adalah 1:9. Kandungan metil ester pada biodiesel yang dihasilkan, yaitu metil stearat, metil linoleat, metil linolenat, dan metil palmitat.

Bobade, S. N., dan Khyade, V. B., 2012, Detail study on the Properties of Pongamia Pinnata (Karanja) for the Production of Biofuel, Research Journal of Chemical Sciences, 2(7): 16-20

Granados, M.L., Poves, M.D.Z., Alonso, D.M., Mariscal, R., Galisteo, F. C., MorenoTost, R, Santamaria, J., Fierro, J. L. G., 2007. Biodiesel from sunflower oil by using activated calcium oxide. Appl. Catal. B Env. 73, 317-326

Guo, F., dan Fang, Z., 2011, Biodiesel Production with solid Catalysts, Biodiesel Feedstocks and Processing Tecnhnologies, 1-21

Hindriyawati, N., Maniam, G. P., Karim, M. R., dan Chong, K. F. 2014. Tranesterification of used cooking oil over alkali metal (Li, Na, K) supported rice husk silica as potential solid base catalyst. Engineering Science and 
Technology, an International Journal, 17(2), 95-103

Istadi, 2011, Teknologi Katalis untuk Konversi Energi: Fundamental dan Aplikasi, Edisi Pertama, Graha Ilmu, Yogayakarta

Knothe, G., van Gerpen, J., dan Krahl, J., 2005, The Biodiesel Handbook, AOCS Press. Champaigne-Illionois

Kumar, D. and Ali, A., 2012, Nanocrystalline $\mathrm{K}-\mathrm{CaO}$ for the transesterification of a variety of feedstocks: Structure, kinetics and catalytic properties, Biomass and bioenergy, 46:459-468

Kumar, D. and Ali, A., 2012, Nanocrystalline $\mathrm{K}-\mathrm{CaO}$ for the transesterification of a variety of feedstocks: Structure, kinetics and catalytic properties, Biomass and bioenergy, 46:459-468

Lam, M. K., Keat Teong Lee., dan A.R., Mohamed, 2010, Homogeneous, heterogenous and enzymatic catalysis for transesterification of high free fatty acid oil (waste cooking oil) to biodiesel: A review, Biotechnology advances, 28, 500-518

Leung, D.Y.C., Wu, Xuan, Leung, M.K.H., 2010, A Review on Biodiesel Production Using Catalyzed Transesterification, Aplied Energy 87: 1083-1095
Meher, L. C., Dharmagadda, V. S. S., dan Naik, S. N. 2006, Optimization of alkalicatalyzed Tranesterification of Pongamia pinnata oil for production of biodiesel. Bioresource Technology, 97, 1392-1397

Niju, S., Begum, K. M. M. S. And Anantharaman, N., 2014, Enchancement of Biodiesel Synthesis Over Highly Active Cao Derived from Naturan White Bivalve Clam Shell, Arabian Journal of Chemistry, 1-7

Silam. 1998. Ekstraksi Minyak Biji Kraet (Hevea brasiliensis) dengan Alat Pengempa Berulir (expeller) dan Karakteristik Mutu Minyaknya, Skripsi, Bogor. Fakultas Teknologi Pertanian. Institut Pertanian Bogor.

Srivastava, A., and Prasad, R., 2000, Triglycerides based Diesel Fuel, Renewable and Sustainable Energy Reviews, 4, 111-133 